\title{
Usefulness of the nCounter Analysis System to Monitor Immune-related Biomarkers in PBMCs During Anti-PD-1 Therapy
}

\author{
TAKAFUMI MORISAKI ${ }^{1,2^{*}}$, MAKOTO KUBO ${ }^{1,2^{*}}$, MASAYO UMEBAYASHI ${ }^{2}$, \\ YUAN YUAN $^{3}$, AKIHIRO TSUYADA ${ }^{3}$, HIROTO TANAKA ${ }^{2}$, NORIHIRO KOYA ${ }^{2}$, \\ SHINICHIROU NAKAGAWA ${ }^{2}$, TAKASHI MORISAKI ${ }^{2}$ and MASAFUMI NAKAMURA ${ }^{1}$ \\ ${ }^{1}$ Department of Surgery and Oncology, Graduate School of Medical Sciences, Kyushu University, Fukuoka, Japan; \\ ${ }^{2}$ Fukuoka General Cancer Clinic, Fukuoka, Japan; \\ ${ }^{3}$ Genetic Analysis Department, RIKEN GENESIS CO., LTD, Tokyo, Japan
}

\begin{abstract}
Background/Aim: Immune checkpoint inhibitors (ICIs) have dramatically changed the clinical outcomes of advanced tumours. However, biomarkers for monitoring immunological features during immunotherapy remain unclear, especially those in the peripheral blood, which are easily available. This study evaluated the usefulness of $n$ Counter Analysis System in identifying immunological biomarkers in peripheral blood mononuclear cells (PBMCs) during ICI therapy. Patients and Methods: PBMCs from two patients who responded well to ICI therapy were used, and the expression levels of immune-related mRNA and extracellular proteins were analyzed. Results: Changes in the expression levels of 55 genes from pre-treatment to on-treatment were bioinformatically similar between the two cases. The expression levels of PD-1 were consistent with those by flow cytometry analysis, a reliable tool for monitoring various markers. Conclusion: The nCounter Analysis System may be a potent tool to simultaneously investigate genes and proteins on PBMCs as biomarkers during immunotherapy using a small amount of sample.
\end{abstract}

Although cancer is still the second leading cause of death worldwide, advances in cancer biology and immunology

This article is freely accessible online.

*These Authors contributed equally to this study.

Correspondence to: Makoto Kubo, MD, Ph.D., Department of Surgery and Oncology, Graduate School of Medical Sciences, Kyushu University, 3-1-1 Maidashi, Higashi-ku, Fukuoka 812-8582, Japan. Tel: +81 926425441, Fax: +81 926425458, e-mail: mkubo@surg1.med.kyushu-u.ac.jp

Key Words: nCounter Analysis System, peripheral blood mononuclear cells, gene and protein profiling, immune checkpoint inhibitor, biomarker. research have improved the survival rates of this disease. Notably, immune-checkpoint inhibitors (ICIs) have completely changed the therapeutic landscape of malignant solid tumours (1-5). However, with the clinical effects of ICIs being different from those of conventional anticancer drugs, making it difficult to manage ICI treatment. For example, although administered ICI function correctly, tumour size can increase, a phenomenon termed "pseudo progression" (6). In addition, other adverse events include various immune-related diseases (7). Therefore, predictive markers for treatment and parameters that provide an indication for monitoring the effects of treatment are needed. Cancer immunology research has mainly focused on the local tumour immune microenvironment (TIME) (8), and the investigation of biomarker responses to ICIs has conventionally focused on the analysis of static time points in tissues or samples taken just before the start of treatment (912). Although TIME may be the most accurate indicator of responses of tumours to PD-1 blockade $(13,14)$, it is unrealistic to obtain tissues regularly just to monitor treatment. Therefore, easily available specimens such as blood are ideal. However, optimal strategies for monitoring peripheral immunity as a surrogate marker for antitumor immunity in TIME remain still elusive.

A recent study reported that peripheral immune activation was required for antitumor immune responses in mouse models (15). Another study reported that the proliferation of peripheral blood Ki67+PD-1+CTLA-4+CD8 T cells within 4 weeks after PD-1 blockade might be associated with a positive clinical outcome (16). These studies suggest that peripheral blood analysis may become a valuable strategy to monitor systemic immunological changes that might represent TIME.

Recently, the nCounter Analysis System (NanoString), which is based on a digital molecular barcode technology that accurately quantitates low-abundance transcripts without the need for amplification, has been used in research and 


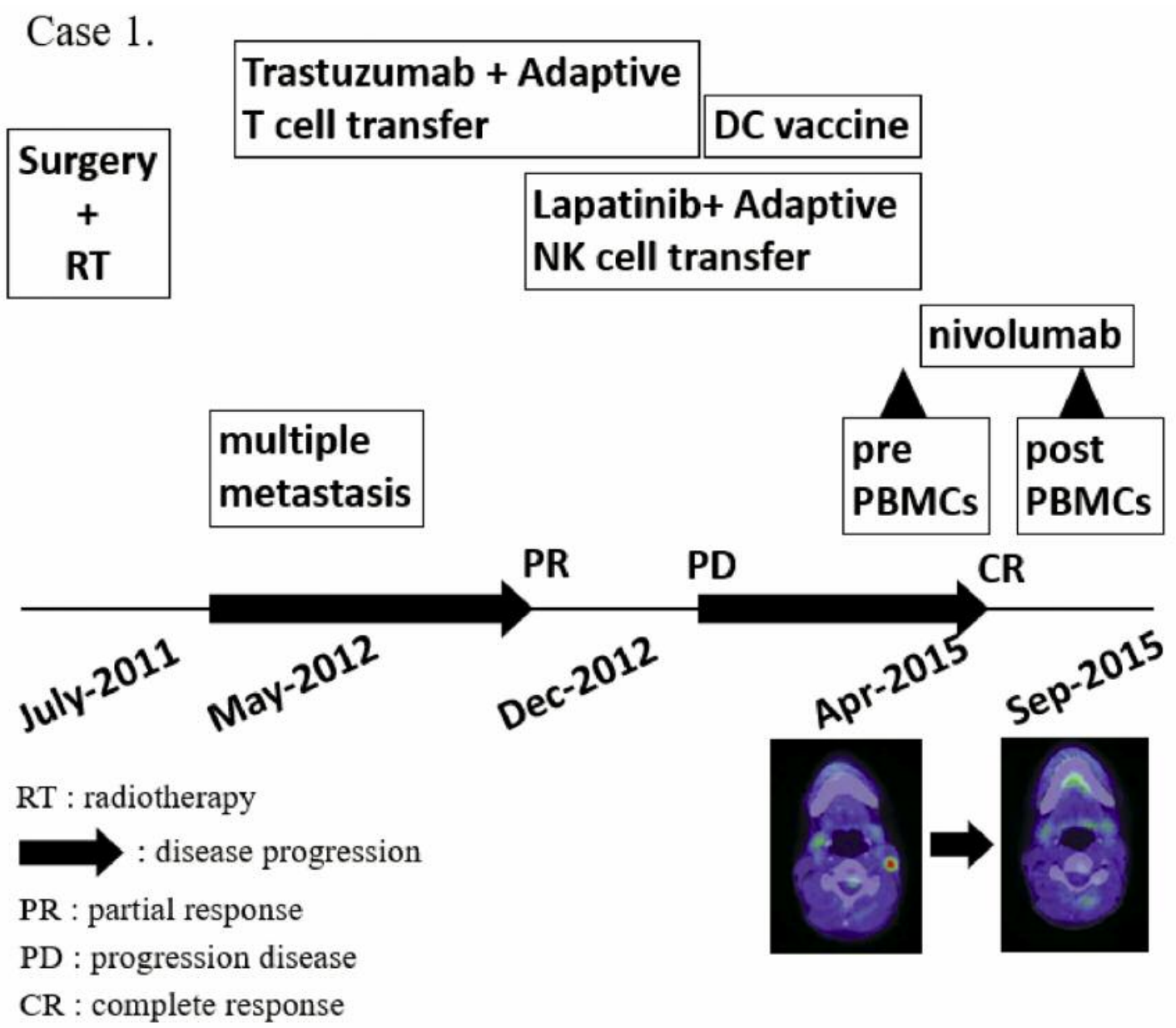

Figure 1. A man aged 59 years diagnosed with parotid cancer in July 2011 had surgery and radiotherapy as first treatment. Ten months later, multiple metastasis in the lung and one in the lymph node were detected. A pathological study of a surgically resected specimen showed Her $2(3+) ;$ therefore, anti-Her 2 therapy and adaptive immunotherapy were administered. After 3 years of therapy, the disease could not be controlled and the patient was administered Nivolumab, which induced a complete response. RT: Radiotherapy; $\rightarrow$ disease progression; PR: partial response; PD: progression decrease; $C R$ : complete response.

clinical situations (17). In this study, we examined whether the nCounter Analysis System is useful for the analysis of immune-related genes and proteins in peripheral blood mononuclear cells (PBMCs) as biomarkers for the therapeutic effect of immunotherapy.

\section{Patients and Methods}

Patients. Clinical and immunological parameters of two patients were investigated in this study. Both patients had histologically proven advanced-stage cancer. One had parotid gland cancer (case 1, Figure 1), and the other had maxillary cancer (case 2, Figure 2). Despite treatment with surgery, chemotherapy, radiotherapy, and adoptive immunotherapy, disease in both cases was progressing at the time of the introduction of nivolumab, a PD-1 inhibitor. Written informed consent was obtained from both patients. The cell processing and adoptive immunotherapy procedures were approved by the Ethics Committee of Fukuoka General Cancer Clinic (FGCCEC001), based on the Act on Securement of Safety on Regenerative Medicine in Japan.

Treatment protocol. Patients received nivolumab every 2 to 3 weeks. At various time points, before and on-treatment, the therapeutic effect was evaluated by tumour markers and imaging (computed tomography or fluorodeoxyglucose positron emission tomography), according to the Response Evaluation Criteria in Solid Tumours v1.1 (RECIST).

PBMC preparation. We obtained peripheral blood just before the first administration of nivolumab and about 4 months later. A complete response in case 1 and a good partial response in case 2 were achieved at the point of second sampling. PBMCs were collected using Ficoll-Paque separation media and cryopreserved at $-80^{\circ} \mathrm{C}$. PBMCs before nivolumab treatment are referred as "Pre PBMCs", and those on-treatment as "Post PBMCs". 


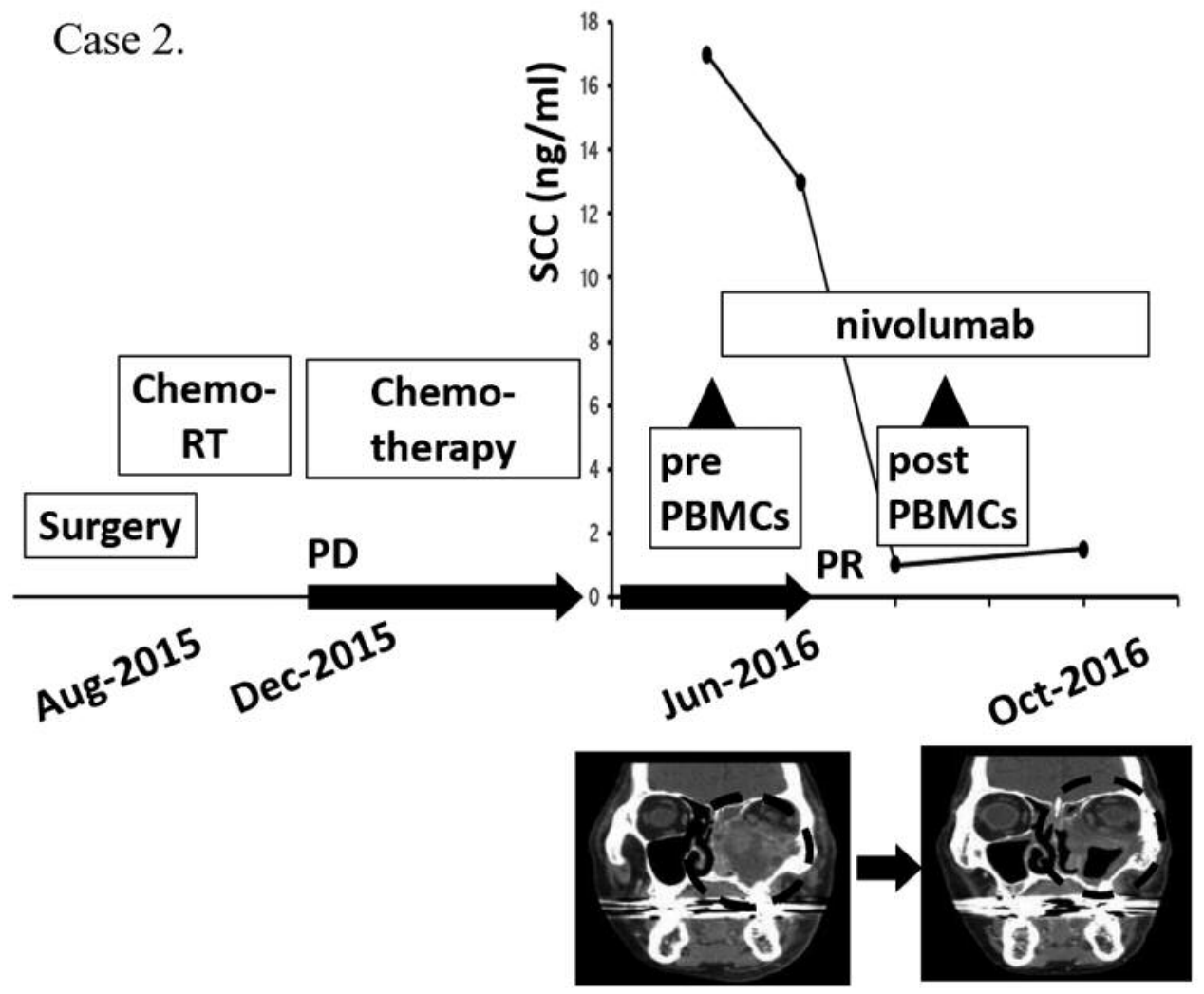

Figure 2. A 71-year-old man diagnosed with maxillary cancer in August 2015 had cytoreduction surgery and adjuvant chemoradiotherapy (CDDP) as first treatment. Soon after, the primary tumor recurred and two regimens of chemotherapies were administered (5-FU+CDDP + cetuximab, paclitaxel+cetuximab). The disease continued to progress and Nivolumab was administered in June 2016. The patient had a good response to Nivolumab therapy. RT: Radiotherapy; $\rightarrow$ disease progression; PR: partial response; PD: progression decrease; SCC: squamous cell carcinoma.

Gene-expression and cell surface protein profiling using the $n$ Counter system. RNA and protein lysates were prepared from PBMCs using the nCounter Vantage Assays Cell SurfaceCompatible Universal Cell Capture Kit. Gene expression levels were analysed using $4 \mu \mathrm{l}$ of prepared RNA lysate, and protein expression levels were analysed using $1 \mu \mathrm{l}$ of prepared protein lysate following the nCounter Vantage 3D RNA:Protein Immune Cell Profiling Panel for Cell Suspensions protocol.

The RNA:Protein Immune Cell Profiling Panel (NanoString Technologies), which consists of 770 genes and 31 cell surface proteins related to immune cells, was used for nCounter-based geneexpression and cell surface protein measurements. Sample-tosample normalization was performed using 40 housekeeping genes.

Statistical analysis. Data analysis was performed with nSolver 3.0 Analysis Software. Agglomerative hierarchical clustering of genes and proteins was preformed using Euclidean distance method to calculate the distance between two samples or genes and Average linkage method to calculate the distance between two clusters.

Monoclonal antibodies and flow cytometry. Cell Surface markers on PBMCs were labelled by immunofluorescence using the monoclonal antibody anti-PD-1-PC7 (Immunotech Beckman Coulter, Brea, CA, USA). After labelling with monoclonal antibodies for $60 \mathrm{~min}$ at $4^{\circ} \mathrm{C}$, fluorescence was detected using an FC500 flow cytometer (Beckman Coulter) and presented as percentage above baseline.

\section{Results}

Differentially expressed genes on PBMCs between pre- and on-treatment of PD-1 blockade. A total of 770 genes contained in the nCounter RNA:Protein Immune Cell Profiling Panel expressed on PBMCs were assessed. Among these genes, the expression levels of 55 genes were similar between the pre-treatment and on-treatment time points in both cases. Of these genes, 15 were down-regulated and 40 were up-regulated after PD-1 blockade (Figure 3).

Consistency of the results between nCounter System Analysis and FACS analysis. We examined 31 immune-related extracellular proteins with nCounter Analysis in PBMCs, which showed the down-regulation of PD-1 expression after PD-1 blockade (Table I). Consistent with this result, FACS analysis demonstrated that cell surface expression levels of PD-1 on PBMCs were down-regulated after PD-1 blockade in both cases (Figure 4). 


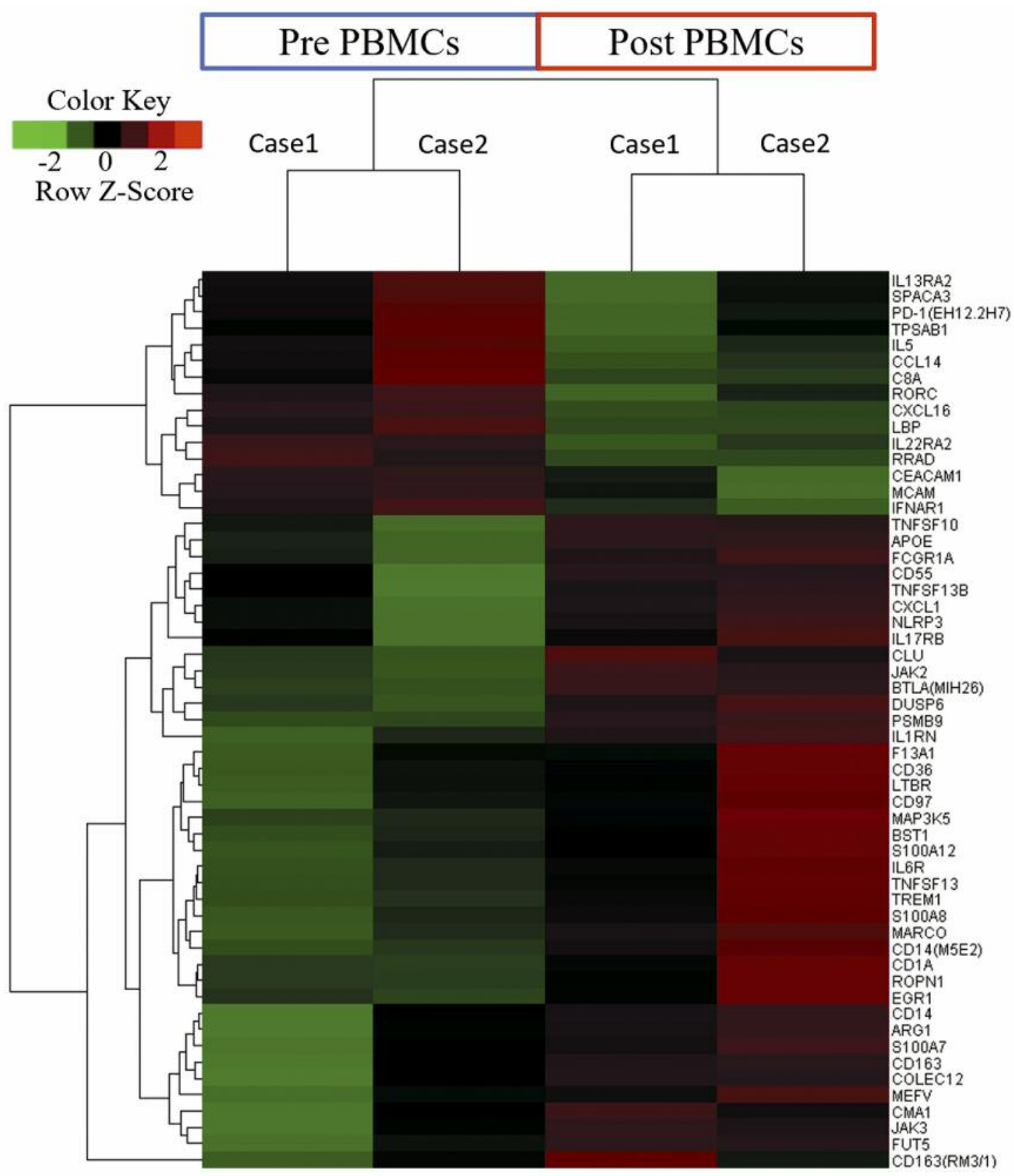

Figure 3. Heatmap visualising the expression levels of 55 mRNAs in PBMCs shows bioinformatically similar changes between pre-treatment to ontreatment in the two cases. Data for 15 down-regulated and 40 up-regulated mRNAs are shown. Hierarchical clustering of the mRNAs based on expression patterns is also shown. Data were normalized using the default setting of nSolver which includes both the positive control normalization to remove the platform-associated sources of variation and the housekeeping gene normalization to remove sample input variability.

\section{Discussion}

This is the first preliminary report to show the use of the nCounter Analysis System to identify biomarkers on PBMCs to determine the effectiveness of ICI treatment. In the present study, the expression levels of immune-related mRNA and extracellular proteins from PBMCs before and on-treatment of anti-PD-1 therapy were analyzed in two advanced cancer patients who responded well to treatment. Of the 770 genes examined, 55 showed similar changes in expression levels at pre-treatment and on-treatment timepoints between the two cases; 15 genes were down-regulated and 40 genes were up-regulated.

Among the 40 up-regulated genes, about twenty genes were reported to be preferentially expressed on myeloid 
Table I. Expression of 31 cell surface immune-related proteins in PBMCs.

\begin{tabular}{|c|c|c|c|c|}
\hline Protein name & $\begin{array}{c}\text { Case } 1 \\
\text { Pre PBMCs }\end{array}$ & $\begin{array}{c}\text { Case } 1 \\
\text { Post PBMCs }\end{array}$ & $\begin{array}{c}\text { Case2 } \\
\text { Pre PBMCs }\end{array}$ & $\begin{array}{c}\text { Case2 } \\
\text { Post PBMCs }\end{array}$ \\
\hline 4-1BB (4B4-1) & 320.4 & 327.2 & 360.14 & 336.06 \\
\hline BTLA (MIH26) & 274.63 & 303.28 & 272.36 & 300.64 \\
\hline CD127 (A019D5) & 1408 & 850.03 & 1018.08 & 1021.37 \\
\hline CD14 (M5E2) & 573.23 & 777.42 & 602.97 & 943.12 \\
\hline CD163 (RM3/1) & 644.06 & 748.37 & 695.67 & 673.77 \\
\hline CD19 (SJ25C1) & 3912.33 & 1957.22 & 1506.2 & 804.74 \\
\hline CD27 (M-T271) & 6959.38 & 4129.72 & 4587.52 & 3957.8 \\
\hline CD28 (CD28.2) & 1490.83 & 1164.42 & 1607.93 & 1537 \\
\hline CD33 (WM53) & 8902.47 & 10246.55 & 13696.92 & 12062.03 \\
\hline CD3E (OKT3) & 3322.76 & 1893.14 & 5316.83 & 4461.9 \\
\hline CD4 (OKT4) & 1032.03 & 650.98 & 1050.9 & 1138.33 \\
\hline CD40 (HB14) & 8965.67 & 6235.58 & 3401.26 & 2021.32 \\
\hline CD40L (24-31) & 604.83 & 573.24 & 488.12 & 534.57 \\
\hline CD45 (HI30) & 61679.74 & 40405.28 & 61867.49 & 57867.12 \\
\hline CD45RO (UCHL1) & 196.16 & 167.44 & 203.45 & 265.23 \\
\hline CD68 (Y1/82A) & 366.17 & 373.33 & 403.62 & 414.31 \\
\hline CD8A (SK1) & 8337.96 & 4790.95 & 14540.26 & 16273.53 \\
\hline CD9 (HI9a) & 49161.37 & 133883.5 & 85397.38 & 55449.61 \\
\hline CTLA-4 (L3D10) & 562.33 & 438.26 & 444.64 & 490.92 \\
\hline GITR (621) & 385.78 & 469.01 & 440.54 & 410.19 \\
\hline HLA-DRA (L243) & 23470.73 & 12617.25 & 24576.69 & 18234.73 \\
\hline $\operatorname{ICOS}(\mathrm{C} 398.4 \mathrm{~A})$ & 1543.14 & 1039.69 & 1705.55 & 1742.09 \\
\hline IL2R (M-A251) & 338.92 & 334.89 & 359.32 & 369.83 \\
\hline KIR3DL1 (DX9) & 2504.33 & 1448.05 & 370.81 & 450.56 \\
\hline NCAM (5.1H11) & 1701.16 & 1135.37 & 1433.19 & 2021.32 \\
\hline NKP46 (9E2) & 622.27 & 704.8 & 908.15 & 770.97 \\
\hline NT5E (AD2) & 2195.92 & 1382.27 & 872.05 & 691.07 \\
\hline OX40 (Ber-АCT35) & 614.64 & 626.21 & 611.18 & 605.41 \\
\hline PD-1 (EH12.2H7) & 380.34 & 222.12 & 537.34 & 302.19 \\
\hline PD-L1 (29E.2A3) & 948.11 & 1644.54 & 1370.02 & 896.17 \\
\hline PD-L2 (MIH18) & 855.48 & 991.85 & 983.63 & 924.17 \\
\hline
\end{tabular}

cells. This was consistent with the protein analysis of post PBMCs showing up-regulation of CD14 (Table I), which is specifically expressed on myeloid cells. A recent study reported that the frequency of peripheral myeloid cells predicted responses to PD-1 blockade, with responders having higher frequencies of $\mathrm{CD} 14^{+} \mathrm{CD} 16^{-} \mathrm{HLA}^{-D R}{ }^{\text {hi }}$ monocytes before ICI therapy (18). Although our study compared pre- and post-treatment PBMCs and did not include non-responders to nivolumab, the up-regulation of myeloid related genes may be related to a good response to ICIs. An important finding was the consistency between the nCounter Analysis System and flow cytometry analysis when measuring the expression levels of $\mathrm{PD}-1$ protein on peripheral immune cells. Considering that flow cytometry analysis is widely accepted and thought to be a reliable method for the detection of various proteins, this consistency may validate the use of the nCounter Analysis System to measure mRNA and protein expression levels in PBMCs.

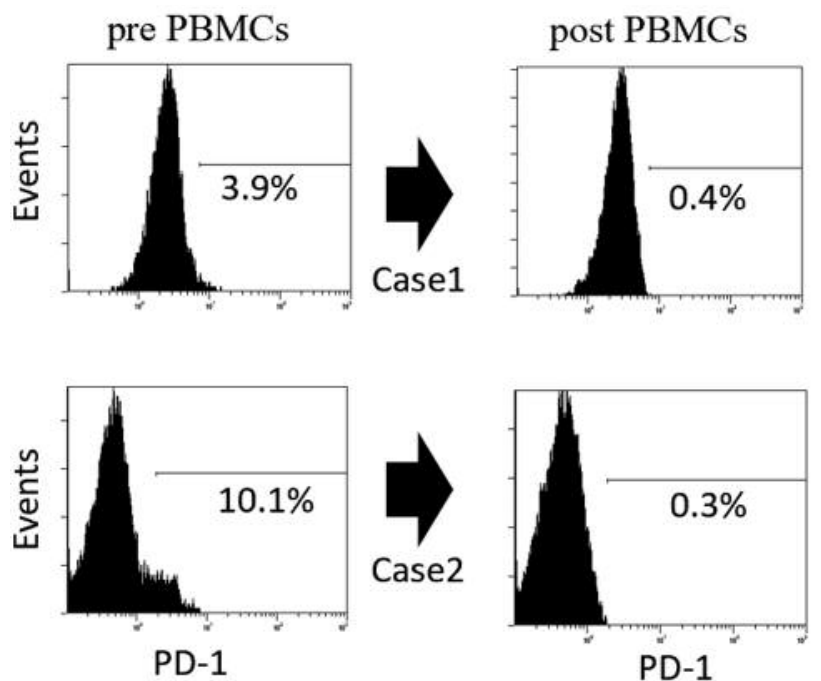

Figure 4. Flow cytometric analysis histograms from PBMCs. 
Based on a phase III, randomized, open-label, ENSURE study, the analysis of circulating tumour DNA (ctDNA) using the cobas ${ }^{\circledR}$ EGFR Mutation Test v2 was approved as a companion diagnostic method for EGFR mutations in lung cancer by the US Food and Drug Administration in June 2016 (19). Analyses of ctDNA allows the estimation of tumour burden in metastatic settings, which is a key biomarker for the use of immune-checkpoint inhibition. Moreover, the analysis of ctDNA including mutations, tumour mutational burden, and microsatellite instability, as a genetic predictor of responsiveness to immunotherapies might be a less invasive surrogate than tumour biopsies (20). Liquid biopsy technology is a promising tool that is being investigated for the early detection of adverse events or resistance to immunotherapies. However, the analysis of ctDNA alone cannot be used to assess tumour microenvironment and immune cell dynamics when ctDNA is used as a monitoring biomarker during the administration of ICIs. Therefore, it is important to simultaneously obtain immune information from tumours as well as PBMCs as a non-invasive method.

There were several limitations in this study. First, the data were not spatially resolved; therefore, the results represent the mean of a variety of PBMCs. This makes it difficult to interpret the results in light of a specific cell type change. To resolve this problem, cell sorting before analysis or using nCounter Single Cell Gene Expression Analysis should be performed. Second, our strategy cannot directly examine whether mRNA and protein expressions in PBMCs can be used as surrogate biomarkers of TIME. To overcome this, the simultaneous analysis of both PBMCs and tumour specimens is necessary. Third, there was a low number of samples per patient. Because overall immunity may change continuously during treatment with immune therapies according to the extent of tumour rejection or systemic response to immunotherapy itself, sampling at numerous timepoints are needed. Last, we must study more patients including non-responders to ICI therapy.

In conclusion, we confirmed that the nCounter Analysis System can be used for mRNA and protein expression monitoring in PBMCs in patients undergoing immunotherapy. This system may be a valuable tool for identifying biomarkers of immunotherapies.

\section{Conflicts of Interest}

There are no conflicts of interest to disclose regarding this study.

\section{Authors' Contributions}

Takafumi Morisaki, M Kubo, and Takashi Morisaki conceived and designed the study; Takafumi Morisaki, M Kubo, MU, YY, AT, HT, NK, SN, and Takashi Morisaki performed the experiments; Takafumi Morisaki, M Kubo, YY, AT, and Takashi Morisaki analysed the data; Takafumi Morisaki and M Kubo drafted the manuscript; $\mathrm{MN}$ provided intellectual input.

\section{Acknowledgements}

The Authors would like to thank Edanz Group (www.edanzediting.com/ac) for editing a draft of this manuscript. Funding: This work was supported by Japan Society for the Promotion of Science KAKENHI Grant Number 18K08577.

\section{References}

1 Topalian SL, Sznol M, McDermott DF, Kluger HM, Carvajal RD, Sharfman WH, Brahmer JR, Lawrence DP, Atkins MB, Powderly JD, Leming PD, Lipson EJ, Puzanov I, Smith DC, Taube JM, Wigginton JM, Kollia GD, Gupta A, Pardoll DM, Sosman JA and Hodi FS: Survival, durable tumor remission, and long-term safety in patients with advanced melanoma receiving nivolumab. J Clin Oncol 32(10): 1020-1030, 2014. PMID: 24590637. DOI: $10.1200 / \mathrm{JCO} .2013 .53 .0105$

2 Topalian SL, Hodi FS, Brahmer JR, Gettinger SN, Smith DC, McDermott DF, Powderly JD, Carvajal RD, Sosman JA, Atkins MB, Leming PD, Spigel DR, Antonia SJ, Horn L, Drake CG, Pardoll DM, Chen L, Sharfman WH, Anders RA, Taube JM, McMiller TL, Xu H, Korman AJ, Jure-Kunkel M, Agrawal S, McDonald D, Kollia GD, Gupta A, Wigginton JM and Sznol M: Safety, activity, and immune correlates of anti-PD-1 antibody in cancer. N Engl J Med 366(26): 2443-2454, 2012. PMID: 22658127. DOI: $10.1056 /$ NEJMoa 1200690

3 Brahmer J, Reckamp KL, Baas P, Crinò L, Eberhardt WE, Poddubskaya E, Antonia S, Pluzanski A, Vokes EE, Holgado E, Waterhouse D, Ready N, Gainor J, Arén Frontera O, Havel L, Steins M, Garassino MC, Aerts JG, Domine M, Paz-Ares L, Reck M, Baudelet C, Harbison CT, Lestini B and Spigel DR: Nivolumab versus docetaxel in advanced squamous-cell nonsmall-cell lung cancer. N Engl J Med 373(2): 123-135, 2015. PMID: 26028407. DOI: 10.1056/NEJMoa1504627

4 Borghaei H, Paz-Ares L, Horn L, Spigel DR, Steins M, Ready NE, Chow LQ, Vokes EE, Felip E, Holgado E, Barlesi F, Kohlhäufl M, Arrieta O, Burgio MA, Fayette J, Lena H, Poddubskaya E, Gerber DE, Gettinger SN, Rudin CM, Rizvi N, Crinò L, Blumenschein GR Jr., Antonia SJ, Dorange C, Harbison CT, Graf Finckenstein F and Brahmer JR: Nivolumab versus docetaxel in advanced nonsquamous non-small-cell lung cancer. N Engl J Med 373(17): 1627-1639, 2015. PMID: 26412456. DOI: $10.1056 /$ NEJMoa1507643

5 Motzer RJ, Escudier B, McDermott DF, George S, Hammers HJ, Srinivas S, Tykodi SS, Sosman JA, Procopio G, Plimack ER, Castellano D, Choueiri TK, Gurney H, Donskov F, Bono P, Wagstaff J, Gauler TC, Ueda T, Tomita Y, Schutz FA, Kollmannsberger C, Larkin J, Ravaud A, Simon JS, Xu LA, Waxman IM and Sharma P; CheckMate 025 Investigators: Nivolumab versus everolimus in advanced renal-cell carcinoma. N Engl J Med 373(19): 1803-1813, 2015. PMID: 26406148. DOI: 10.1056/NEJMoa1510665

6 Hodi FS, Hwu WJ, Kefford R, Weber JS, Daud A, Hamid O, Patnaik A, Ribas A, Robert C, Gangadhar TC, Joshua AM, Hersey P, Dronca R, Joseph R, Hille D, Xue D, Li XN, Kang SP, Ebbinghaus S, Perrone A, and Wolchok JD: Evaluation of immune-related response criteria and RECIST v1.1 in patients with advanced melanoma treated with pembrolizumab. J Clin Oncol 34(13): 1510-1517, 2016. PMID: 26951310. DOI: 10.1200/JCO.2015.64.0391 
7 Postow MA: Managing immune checkpoint-blocking antibody side effects. Am Soc Clin Oncol Educ Book 76-83, 2015. PMID: 25993145. DOI: 10.14694/EdBook_AM.2015.35.76

8 Maman S and Witz IP: A history of exploring cancer in context. Nat Rev Cancer 18(6): 359-376, 2018. PMID: 29700396. DOI: 10.1038/s41568-018-0006-7

9 Rizvi NA, Hellmann MD, Snyder A, Kvistborg P, Makarov V, Havel JJ, Lee W, Yuan J, Wong P, Ho TS, Miller ML, Rekhtman N, Moreira AL, Ibrahim F, Bruggeman C, Gasmi B, Zappasodi R, Maeda Y, Sander C, Garon EB, Merghoub T, Wolchok JD, Schumacher TN and Chan TA: Cancer immunology. Mutational landscape determines sensitivity to PD-1 blockade in non-small cell lung cancer. Science 348(6230): 124-128, 2015. PMID: 25765070. DOI: $10.1126 /$ science.aaa1348

10 Tumeh PC, Harview CL, Yearley JH, Shintaku IP, Taylor EJ, Robert L, Chmielowski B, Spasic M, Henry G, Ciobanu V, West AN, Carmona M, Kivork C, Seja E, Cherry G, Gutierrez AJ, Grogan TR, Mateus C, Tomasic G, Glaspy JA, Emerson RO, Robins H, Pierce RH, Elashoff DA, Robert C and Ribas A: PD1 blockade induces responses by inhibiting adaptive immune resistance. Nature 515(7528): 568-571, 2014. PMID: 25428505. DOI: $10.1038 /$ nature 13954

11 Taube JM, Klein A, Brahmer JR, Xu H, Pan X, Kim JH, Chen L, Pardoll DM, Topalian SL and Anders RA: Association of PD1, PD-1 ligands, and other features of the tumor immune microenvironment with response to anti-PD-1 therapy. Clin Cancer Res 20(19): 5064-5074, 2014. PMID: 24714771. DOI: 10.1158/1078-0432.CCR-13-3271

12 Shibutani M, Maeda K, Nagahara H, Fukuoka T, Nakao S, Matsutani S, Hirakawa $\mathrm{K}$ and Ohira $\mathrm{M}$ : The prognostic significance of the tumor-infiltrating programmed cell death-1+ to $\mathrm{CD}^{+}+$lymphocyte ratio in patients with colorectal cancer. Anticancer Res 37(8): 4165-4172, 2017. PMID: 28739701. DOI: 10.21873/anticanres.11804

13 Fridman WH, Pagès F, Sautès-Fridman C and Galon J: The immune contexture in human tumours: impact on clinical outcome. Nat Rev Cancer 12(4): 298-306, 2012. PMID: 22419253. DOI: $10.1038 / \mathrm{nrc} 3245$

14 Binnewies M, Roberts EW, Kersten K, Chan V, Fearon DF, Merad M, Coussens LM, Gabrilovich DI, Ostrand-Rosenberg S, Hedrick CC, Vonderheide RH, Pittet MJ, Jain RK, Zou W, Howcroft TK, Woodhouse EC, Weinberg RA and Krummel MF: Understanding the tumor immune microenvironment (TIME) for effective therapy. Nat Med 24(5): 541-550, 2018. PMID: 29686425. DOI: 10.1038/s41591-018-0014-x
15 Spitzer MH, Carmi Y, Reticker-Flynn NE, Kwek SS, Madhireddy D, Martins MM, Gherardini PF, Prestwood TR, Chabon J, Bendall SC, Fong L, Nolan GP and Engleman EG: Systemic immunity is required for effective cancer immunotherapy. Cell 168(3): 487502.e15, 2017. PMID: 28111070. DOI: 10.1016/j.cell.2016.12.022

16 Kamphorst AO, Pillai RN, Yang S, Nasti TH, Akondy RS, Wieland A, Sica GL, Yu K, Koenig L, Patel NT, Behera M, Wu H, McCausland M, Chen Z, Zhang C, Khuri FR, Owonikoko TK, Ahmed R and Ramalingam SS: Proliferation of PD-1+ CD8 $\mathrm{T}$ cells in peripheral blood after PD-1-targeted therapy in lung cancer patients. Proc Natl Acad Sci USA 114(19): 4993-4998, 2017. PMID: 28446615. DOI: 10.1073/pnas.1705327114

17 Hyeon J, Cho SY, Hong ME, Kang SY, Do I, Im YH and Cho EY: NanoString nCounter ${ }^{\circledR}$ Approach in Breast Cancer: A comparative analysis with quantitative real-time polymerase chain reaction, in situ hybridization, and immunohistochemistry. J Breast Cancer 20(3): 286-296, 2017. PMID: 28970855. DOI: 10.4048/jbc.2017.20.3.286

18 Krieg C, Nowicka M, Guglietta S, Schindler S, Hartmann FJ, Weber LM, Dummer R, Robinson MD, Levesque MP and Becher B: High-dimensional single-cell analysis predicts response to anti-PD-1 immunotherapy. Nat Med 24(2): 144-153, 2018. PMID 29309059. DOI: $10.1038 / \mathrm{nm} .4466$

19 Wu YL, Zhou C, Liam CK, Wu G, Liu X, Zhong Z, Lu S, Cheng Y, Han B, Chen L, Huang C, Qin S, Zhu Y, Pan H, Liang H, Li E, Jiang G, How SH, Fernando MC, Zhang Y, Xia F and Zuo Y: First-line erlotinib versus gemcitabine/cisplatin in patients with advanced EGFR mutation-positive non-small-cell lung cancer: analyses from the phase III, randomized, open-label, ENSURE study. Ann Oncol 26(9): 1883-1889, 2015. PMID: 26105600. DOI: $10.1093 /$ annonc/mdv270

20 Cabel L, Proudhon C, Romano E, Girard N, Lantz O, Stern MH, Pierga JY and Bidard FC: Clinical potential of circulating tumour DNA in patients receiving anticancer immunotherapy. Nat Rev Clin Oncol 15(10): 639-650, 2018. PMID: 30050094. DOI: $10.1038 / \mathrm{s} 41571-018-0074-3$
Received May 29, 2019

Revised June 24, 2019

Accepted June 25, 2019 